\title{
Noteworthy lichenicolous fungi and lichens from Russia
}

\author{
Mikhail P. Zhurbenko \\ Laboratory of the Systematics and Geography of Fungi, Komarov Botanical Institute, Russian Academy of Sciences, \\ Professora Popova, 2, St. Petersburg, 197376, Russia \\ E-mail: zhurb58@gmail.com
}

\begin{abstract}
Notes are presented on seven species of lichenicolous, non-lichenized and lichenized fungi found in the Asian part of Russia. Endococcus pseudocarpus is reported for the first time for Northern Asia as well as for the Irkutsk Region of Russia. Plectocarpon hypogymniae and P. nephromeum are reported new to the Irkutsk Region, Taeniolella diploschistis new to the Republic of Sakha (Yakutia), Steinia geophana new to Chukotka Autonomous Area, and Epigloea soleiformis new to the north of the Krasnoyarsk Territory of Russia. Hypogymnia physodes is reported as a new host species for Plectocarpon hypogymniae.
\end{abstract}

Keywords: biodiversity, biogeography, lichen parasites, Siberia

\section{INTRODUCTION}

This publication continues a series of notes by the author on findings of lichenicolous fungi and lichens from the Holarctic that are of interest in terms of their taxonomy, geography, or ecology (see also: Zhurbenko, 2009a, b; 2010; 2020; 2021). This paper is based on material collected by the author and by I. I. Makarova and A. N. Titov in arctic and subarctic biomes of Central and North-Eastern Siberia and the Russian Far East, as well as in boreal biomes of Southern Siberia. All collection sites are located in the Asian part of Russia and administratively belong to its Chukotka Autonomous Area, Irkutsk Region, Krasnoyarsk Territory or Sakha-Yakutiya Republic.

\section{MATERIAL AND METHODS}

The material used for this study is deposited in the mycological herbarium of the V. L. Komarov Botanical Institute in St. Petersburg, Russia (LE). Microscopic examinations and photography were carried out using a Zeiss Stemi 2000-CS dissecting microscope, fitted with an AxioCam MRc 5 digital camera, and a Zeiss Axio Imager A1 compound microscope equipped with Nomarski differential interference contrast optics, fitted with an Axiocam 506 digital camera. Microscopic characters were studied using razor blade cut sections mounted in water, $10 \%$ potassium hydroxide $(\mathrm{K})$, concentrated nitric acid $(\mathrm{N})$ or Lugol's iodine, directly (I) or after a K pre-treatment (K/I). Measurements were taken from water mounts and rounded to the nearest $0.5 \mu \mathrm{m}$. The length, width, and length/width ratio $(1 / w)$ of ascospores are given (when $n>10$ ) as (min-) $(\bar{x}-\mathrm{SD})-(\bar{x}+\mathrm{SD})(-\max )$, where 'min' and 'max' are the extreme values observed, ' $\bar{x}$ ' the arithmetic mean, and 'SD' the corresponding standard deviation. The examined specimens of lichenicolous fungi were collected by the author or found by him in the lichen collections of I. I. Makarova and A. N. Titov, which were made available to him by the collectors.

\section{THE SPECIES}

ENDOCOCCUS PSEUdOCARPUS Nyl.

Perithecia black, glossy, with a rather smooth surface, subglobose, ostiolate, 160-250 $\mu \mathrm{m}$ diam., protruding in the ostiolar area, up to $1 / 2$ exposed above the host surface (Fig. 1). Asci subcylindrical to very narrowly clavate, $66-76 \times$ 9-11 $\mu \mathrm{m}, 8$-spored. Ascospores brownish orange, narrowly ellipsoid or oblanceolate, 1 -septate, sometimes with slightly narrower and longer lower cell, upper cell length/lower cell length $=0.8-1(\mathrm{n}=20)$, with rather acute ends, $(11-) 13-16.5(-18.5) \times 4-4.5(-5) \mu \mathrm{m}, 1 / \mathrm{w}=$ (2.6-)2.9-3.9(-4.4) (n= 24), not constricted at the septum, usually with 1-2 large guttules in each cell, irregularly 1-2-seriate in the ascus. According to the literature, the size of the ascospores of this species varies considerably: 9-18 $\times$ 5-7 $\mu \mathrm{m}$ (protologue; Nylander, 1873), 12-17 × 3$6 \mu \mathrm{m}$ (Heiðmarsson et al., 2012), 15.5-20 × 5.56.5 (Kocourková-Horáková, 1998), 8.5-15.5 × 3.5-5 $\mu \mathrm{m}$ (Zhurbenko, 2013), 14-15 × 3.5-4.5 $\mu \mathrm{m}$ (Etayo, 2010), 10-15 × 3.5-5 (Brackel, 2014). It is possible that this variation, as well as the rather wide range of hosts, is due to the presence of cryptic taxa. 

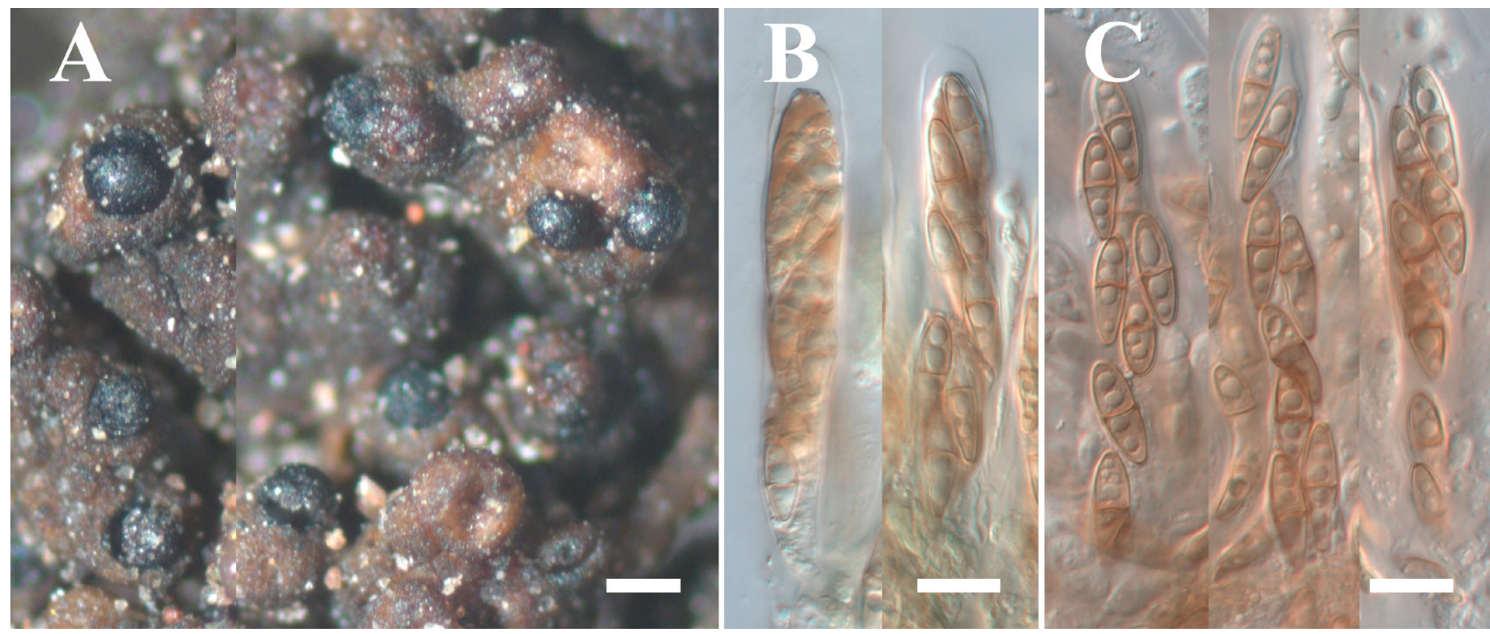

Fig. 1. Endococcus pseudocarpus (Zhurbenko 05200). A - habitus of ascomata on the thallus of Enchylium polycarpon; B - asci, in I; C-ascospores, in water (scale bars: A = $200 \mu \mathrm{m}$; B, C = $10 \mu \mathrm{m}$ ).

This species was described from the French Pyrenees as growing on host lichen probably representing Peltula euploca (as "Heppia guepinii var. nigrolimbata"; Hawksworth \& Diederich, 1988). It was subsequently found in various countries in Europe from Sweden to Spain (Brackel, 2014), in Western Asia (Turkey and the Russian Caucasus; Halıc1 et al., 2007; Urbanavichus \& Urbanavichene, 2014), Canary Islands (van den Boom, 2013), and Northern Africa (Morocco; Maire \& Werner, 1938). It is confined to cyanolichen genera Callome, Enchylium, Lathagrium, Peltula, Placynthium and Scytinium. The species is newly documented here in Northern Asia. In Russia, it was known from the Murmansk Region, Komi Republic, Republic of Adygeya, and Stavropol Territory (Zhurbenko, 2013; Urbanavichus \& Urbanavichene, 2014; Urbanavichus, 2016; Urbanavichene \& Urbanavichus, 2018), and is reported here for the first time from the Irkutsk Region.

Specimen examined. Russia. Irkutsk Region. Baikal Siberia, $4 \mathrm{~km}$ SW of Elantsy, $52^{\circ} 46^{\prime} \mathrm{N}$, $106^{\circ} 21^{\prime} \mathrm{E}$, elev. $590 \mathrm{~m}$, calcareous rocks on steppe slope among taiga forest, on Enchylium polycarpon (thallus), 8 June 2005, M. P. Zhurbenko 05200 (LE 310204)

\section{EPIGLOEA SOLEIFORMIS Döbbeler}

This fungus is associated with algal films growing on various substrates, including lichens (Chambers \& David, 2009), and thus is often noted in lists of lichens and lichenicolous fungi. It is characterized by gelatinous green- or grey-black, glossy perithecia, prosoplectenchymatous, thin exciple, simple, apically not enlarged paraphyses, non-fissitunicate, 8-spored asci with I+ and $\mathrm{K} / \mathrm{I}+$ blue wall, and hyaline, sole-shaped, 1-septate ascospores without appendages (Döbbeler, 1984). This inconspicuous and therefore probably much overlooked species (Sérusiaux et al., 1999) is known from scattered finds in Europe, Asia, North America, South America, New Zealand, and the Subantarctic Islands (Döbbeler, 1984; Fryday, 2000; Buck \& Harris, 2002; Motiejūnaitè et al., 2019; Zhurbenko \& Ohmura, 2019). It has not been reported from the Arctic (Kristinsson et al., 2010), and is listed here for the second time for the Subarctic where it was previously known from Iceland (Berger, 2000). This fungus was known in Russia from the Altai Territory, south of the Krasnoyarsk Territory (Eastern Sayan Mountains), and Trans-Baikal Territory (Zhurbenko, 2010; Zhurbenko et al., 2016; Zhurbenko \& Pino-Bodas, 2017). It is reported here for the first time from the north of the Krasnoyarsk Territory/Central Siberia.

Specimen examined. RUSSIA. Krasnoyarsk Territory. Putorana Plateau, Kapchuk Lake, $69^{\circ} 28^{\prime} \mathrm{N}$, $91^{\circ} 02^{\prime} \mathrm{E}$, elev. $200 \mathrm{~m}$, boulder field in sparse Lar$i x$ taiga forest, on algal films in close association with Psora globifera growing on soil, 11 August 1982, A. N. Titov (LE 310186). 
Micarea intrusa (Th. Fr.) Coppins \& H. Kilias This lichenicolous lichen is characterized by a poorly developed thallus, black apothecia with a disappearing margin, blue- or black-green, $\mathrm{N}+$ red epihymenium, colourless to pale brownish-yellow hypothecium, an exciple formed by radially diverging hyphae, with a dark marginal zone, and hyaline, ellipsoid to oblong, O(-4)-septate ascospores (Andreev, 2003). It mostly grows in close association with Rhizocarpon geographicum and Lecidea lapicida (Hafellner, 2004), but also with many other epilithic lichens, such as Amygdalaria panaeola, Aspicilia cinerea, Calvitimela aglaea, C. melaleuca, Euopsis cf. granatina, Lecidea atrobrunnea, Rhizocarpon lecanorinum, Schaereria fuscocinerea and Varicellaria lactea (Rambold \& Triebel, 1992; Aptroot et al., 1997; Berger, 2000; Hafellner, 2004; Santesson et al., 2004). The species is widespread in the Holarctic (Hinds et al., 2002; Hafellner, 2004; Zhurbenko, 2009a) and was also reported from Papua New Guinea (Aptroot et al., 1997). In Russia, it has been known from scattered localities in the Chukotka Autonomous Area, Komi Republic, Leningrad Region, Murmansk Region, Primorye Territory, Republic of Altai, Republic of Karelia, and Sakhalin Region (Andreev, 2003; Urbanavichus \& Urbanavichene, 2009; Zhurbenko, 2009a; Skirina, 2010; Czernyadjeva et al., 2020; Konoreva et al., 2020).

Specimen examined. Russia. Chukotka Autonomous Area. The surroundings of Puoten Bay, $65^{\circ} 50^{\prime} \mathrm{N}, 170^{\circ} 32^{\prime} \mathrm{W}$, dwarf shrub tundra, on Amygdalaria panaeola (thallus), 23 July 1972, I. I. Makarova (LE 207404).

Plectocarpon hypogymniae Zhurb. \& Diederich (Fig. 2)

This fungus is characterized by superficial, brownish-black, convex, stromatic ascomata with labyrinthiform or lirellate ornamented surface, containing Atra-brown pigment in stromata, with numerous locules 100-170 $\mu \mathrm{m}$ diam., I+ red, K/I+ blue hymenium, branched and anastomosed paraphyses, 8-spored, Opegrapha-type asci with K/I+ blue apical ring, hyaline, fusiform to narrowly skittle-shaped, 3-septate ascospores, (12-)13-15.5(-17) × (3-)3.5-4(-4.5) $\mu \mathrm{m}$, and its confinement to species of Hypogymnia (Zhurbenko et al., 2008). To date, this species is known only from Asia, where it was reported from Russia: Republic of Sakha (Yakutia), Republic of Tuva (holotype), and Trans-Baikal
Territory (Zhurbenko et al., 2008; Zhurbenko \& Vershinina, 2014; Zhurbenko \& Yakovchenko, 2014), and Mongolia (Zhurbenko et al., 2019), growing on Hypogymnia bitteri and $H$. tubulosa. It is reported here as new to the Irkutsk Region of Russia. Hypogymnia physodes is a new host species.

Specimen examined. RUSSIA. Irkutsk Region. Baikal Siberia, $2 \mathrm{~km}$ SE of Anchuk, Bol'shaya Bystraya River, $51^{\circ} 44^{\prime} \mathrm{N}, 103^{\circ} 29^{\prime} \mathrm{E}$, elev. $700 \mathrm{~m}$, Larix-Picea-Pinus taiga forest, on Hypogymnia physodes (thallus), 9 June 2005, M. P. Zhurbenko 0558 (LE 310183).

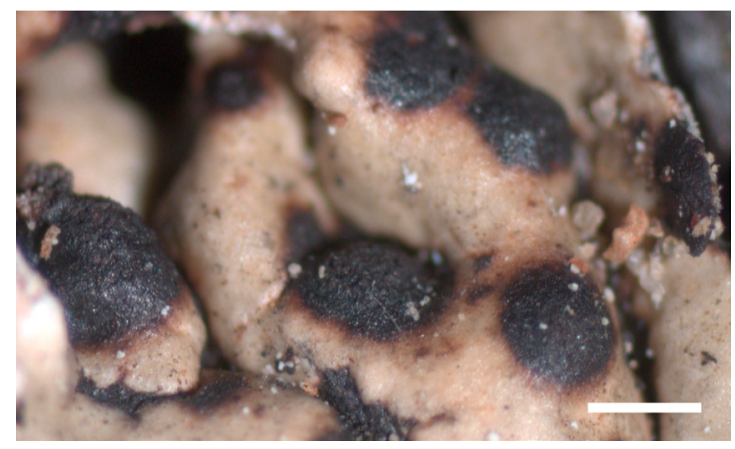

Fig. 2. Plectocarpon hypogymniae (Zhurbenko 0558). Habitus of ascomata on the thallus of Hypogymnia physodes (scale bar $=500 \mu \mathrm{m}$ ).

Plectocarpon NePHROMeum (Norman) R. Sant. This species differs from other members of the genus by its mainly 2 -septate ascospores, dark greenish, not granular, $\mathrm{K}+$ green intensifying, $\mathrm{N}+$ orange brown stromatic pigment, the holarctic distribution, and by its confinement to Nephroma species, mostly to N. bellum (Ertz et al., 2005; Spribille et al., 2020). It was previously known from scattered localities in Europe (Norway, Komi Republic and Murmansk Region of Russia, Sweden), Asia (Kamchatka Territory of Russia), and North America (Canada, U.S.A.) (Goward et al., 1996; Diederich, 2003; Ertz et al., 2005; Urbanavichus et al., 2007; Zhurbenko, 2009b; Spribille et al., 2010; Zhurbenko et al., 2012). It is reported here as new to the Irkutsk Region of Russia.

Specimen examined. Russia. Irkutsk Region. Baikal Siberia, the foothills of the KhamarDaban Range, Snezhnaya River valley, $51^{\circ} 23^{\prime} \mathrm{N}$, $104^{\circ} 39^{\prime} \mathrm{E}$, elev. 550 m, Pinus-Abies taiga forest, 
on Nephroma bellum (thallus), 17 June 2005, M. P. Zhurbenko 05304 (LE 310187).

Steinia Geophana (Nyl.) Stein

This subcosmopolitan lichen is characterized by an inconspicuous thallus resembling algal soil crusts, small, brown-black convex apothecia with rudimentary true exciple, I+ blue hymenial gel, unitunicate, 16-spored asci with a K/ I+ blue tholus, and hyaline, subglobose, thickwalled ascospores (Fletcher et al., 2009). Poelt and Vězda (1990) classified it as a short living lichen, often settled on unstable substrates, like disturbed soil or aged lichen thalli, especially those of the Peltigera species. When it grows on lichens, it often looks like a lichenicolous fungus because of its inapparent thallus and is therefore included in this paper along with the truly lichenicolous species. The species has been documented in many regions of Russia (Urbanavichus, 2010), but has not been reported from the Chukotka Autonomous Area so far.

Specimen examined. RussiA. Chukotka Autonomous Area. Gil'mymlinei hot springs, $15 \mathrm{~km} \mathrm{SE}$ of Ioni Lake, $65^{\circ} 48^{\prime} \mathrm{N}, 173^{\circ} 15^{\circ} \mathrm{W}$, dwarf shrubforb-lichen tundra, on the thallus of Gyalecta sp. and plant remnants on soil, 19 July 1977 , I. I. Makarova (LE 310188).

TAEniolella Diploschistis Heuchert, U. Braun, Diederich \& Zhurb. (Fig. 3)

This hyphomycete is distinct amongst the other lichenicolous Taeniolella species by the formation of stromatic aggregations of swollen hyphal cells up to $80 \mu \mathrm{m}$ wide, rugose, irregularly verrucose, rhagadiose to distinctly rimulose-areolate conidia up to $45 \mu \mathrm{m}$ long, with up to 7 transverse septa, and its confinement to species of Diploschistes (Heuchert et al., 2019). This recently described species was known from France, Luxembourg (holotype), and the Krasnoyarsk Territory of Russia (Heuchert et al., 2019). It is newly reported here for the Republic of Sakha (Yakutia) of Russia.

Specimen examined. Russia. Sakha-Yakutiya Republic. Eastern Siberia, Lena River delta, Stolb (Ebe-Khaya) Island, $72^{\circ} 24^{\prime} \mathrm{N}, 126^{\circ} 40^{\prime} \mathrm{E}$, elev. $50 \mathrm{~m}$, rocks among tundra vegetation, on Diploschistes scruposus (thallus), 12 August 1998, M. P. Zhurbenko 98417 (LE 310182).

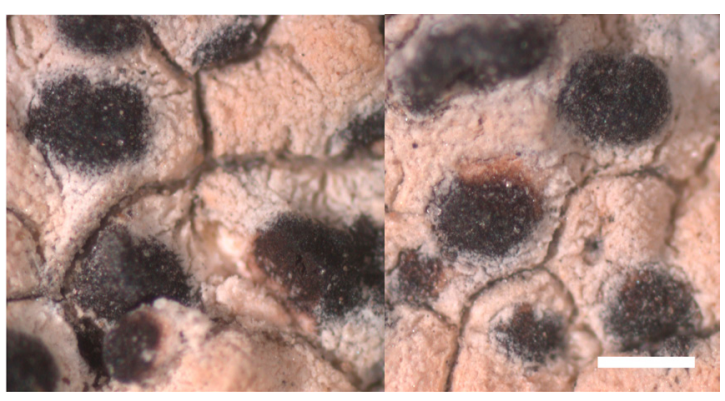

Fig. 3. Taeniolella diploschistis (Zhurbenko 98417). Colonies on the thallus of Diploschistes scruposus (scale bar $=500 \mu \mathrm{m})$.

\section{ACKNOWLEDGEMENTS}

The study of M. P. Zhurbenko was carried out within the framework of the research project of the V. L. Komarov Botanical Institute of the Russian Academy of Sciences "Biodiversity, ecology, structural and functional features of fungi and fungus-like protists" (AAAA-A19-119020890079-6) using equipment of its Core Facility Center "Cell and Molecular Technologies in Plant Science”.

\section{REFERENCES}

Andreev, M. P. 2003. Carbonea. In: Golubkova, N. S. (ed.). Handbook of the lichens of Russia. Issue 8. Nauka, St. Petersburg. Pp. 120-132.

Aptroot, A., Diederich, P., Sérusiaux, E. \& Sipman, H. J. M. 1997. Lichens and lichenicolous fungi from New Guinea. Bibliotheca Lichenologica 64:1-220.

Berger, F. 2000. Beitrag zur Kenntnis der Flechten und lichenicolen Pilze Islands. Acta Botanica Islandica 13: 69-82.

Brackel, W. v. 2014. Kommentierter Katalog der flechtenbewohnenden Pilze Bayerns. Bibliotheca Lichenologica 109: 1-476.

Buck, W. R. \& Harris, R. C. 2002. Epigloea (Epigloeaceae) new to North America. Evansia 19(3): 83-84.

Chambers, S. P. \& David, J. C. 2009. Epigloea Zukal (1890). In: Smith, C. W., Aptroot, A., Coppins, B. J., Fletcher, A., Gilbert, O. L., James, P. W. \& Wolseley, P. A. (eds). The Lichens of Great Britain and Ireland. British Lichen Society, London. Pp. 392-394.

Czernyadjeva, I. V., Afonina, O. M., Davydov, E. A. et al. 2020. New cryptogamic records. 5. Novosti sistematiki nizshikh rastenii 54(1): 261-286. https://doi.org/10.31111/nsnr/2020.54.1.261

Diederich, P. 2003. New species and new records of American lichenicolous fungi. Herzogia 16: 41-90. 
Döbbeler, P. 1984. Symbiosen zwischen Gallertalgen und Gallertpilzen der Gattung Epigloea (Ascomycetes). In: Hertel, H. \& Oberwinkler, F. (eds.). Beitrage zur Lichenologie. Festscrift J. Poelt. Beiheft zur Nova Hedwigia 79: 203-239.

Döbbeler, P. 1994. Epigloea urosperma (Ascomycetes) ein neuer Flechtenparasit. Sendtnera 2: 277-282.

Ertz, D., Christnach, C., Wedin, M. \& Diederich, P. 2005. A world monograph of the genus Plectocarpon (Roccellaceae, Arthoniales). Bibliotheca Lichenologica 91: 1-155.

Etayo, J. 2010. Líquenes y hongos liquenícolas de Aragón. Guineana 16: 1-501.

Fletcher, A., Aptroot, A. \& Purvis, O. W. 2009. Steinia Körb. (1873). In: Smith, C. W., Aptroot, A., Coppins, B. J., Fletcher, A., Gilbert, O. L., James, P. W. \& Wolseley, P. A. (eds). The Lichens of Great Britain and Ireland. British Lichen Society, London. P. 856.

Fryday, A. M. 2000. Additional lichen records from New Zealand 32. Epigloea soleiformis Döbbeler and Fuscidea impolita (Müll. Arg.) Hertel. Australasian Lichenology 47: 30-31.

Goward, T., Breuss, O., Ryan, B., McCune, B., Sipman, H. \& Scheidegger, C. 1996. Notes on the lichens and allied fungi of British Columbia. III. The Bryologist 99: 439-449. https://doi. org/10.2307/3244108

Hafellner, J. 2004. Notes on Scoliciosporum intrusum. Fritschiana 49: 29-41.

Halıc1, M. G., Hawksworth, D. L. \& Aksoy, A. 2007. Contributions to the lichenized and lichenicolous fungal biota of Turkey. Mycotaxon 102: 403-414.

Hawksworth, D. L. \& Diederich, P. 1988. A synopsis of the genus Polycoccum (Dothideales), with a key to accepted species. Transactions of the British Mycological Society 90(2): 293-312. https://doi. org/10.1016/S0007-1536(88)80101-3

Heiðmarsson, S., Alstrup, V., Högnabba, F., Motiejūnaitè, J., Nordin, A., Pykälä, J., Suija, A., Timdal, E. \& Westberg, M. 2012. Floristic news from the NLF Iceland excursion 2009. Graphis Scripta 24: 19-25.

Heuchert, B., Diederich, P., Zhurbenko, M. P. \& Braun, U. 2019. Taeniolella diploschistis sp. nov.a new lichenicolous fungus on Diploschistes scruposus. Herzogia 32: 94-100. https://doi. org/10.13158/heia.32.1.2019.94

Hinds, J. W., Fryday, A. M. \& Dibble, A. C. 2002. Three additions to the lichen flora of North America from Mt. Katahdin, Maine. Evansia 19(4): 137-141.

Kocourková-Horáková, J. 1998. Records of new, rare or overlooked lichens from the Czech Republic. Czech Mycology 50: 223-239. https://doi. org/10.33585/cmy.50307

Konoreva, L., Chesnokov, S., Yakovchenko, L., Ohmura, Y. \& Davydov, E. A. 2020. New records to the lichen biota of Russia, 1 - Sakhalin Region, with new records for the Russian Far East and the Asian part of Russia. Botanica Pacifica 9(2): 1-13. https: / / doi.org/10.17581/bp.2020.09203

Kristinsson, H., Zhurbenko, M. \& Hansen, E. S. 2010. Panarctic checklist of lichens and lichenicolous fungi. CAFF Technical Report No. 20, CAFF International Secretariat, Akureyri, Iceland, July 2010. 120 pp.

Maire, R. \& Werner, R. G. 1938 (1937). Fungi Maroccani. Catalogue raisonné des Champignons connus jusqu’ici au Maroc. Mémoires de la Sociéte des sciences naturelles du Maroc 45: 1-147.

Motiejūnaitè, J., Zhurbenko, M. P., Suija, A. \& Kantvilas, G. 2019. Lichenicolous ascomycetes on Siphula-like lichens, with a key to the species. The Lichenologist 51: 45-73. https://doi. org/10.1017/S0024282918000579

Nylander, W. 1873. Observata lichenologica in Pyrenaeis orientalibus. Flora (Regensburg) 56: 193-208.

Poelt, J. \& Vězda, A. 1990. Uber kurzlebige Flechten. In: H. M. Jahns (ed.). Contributions to lichenology in honour of A. Henssen. Bibliotheca Lichenologica 38: 377-394.

Rambold, G. \& Triebel, D. 1992. The inter-lecanoralean associations. Bibliotheca Lichenologica 48: 1-201.

Santesson, R., Moberg, R., Nordin, A., Tønsberg, T. \& Vitikainen, O. 2004. Lichen-forming and lichenicolous fungi of Fennoscandia. Museum of Evolution, Uppsala University. 359 pp.

Sérusiaux, E., Diederich, P., Brand, A. M. \& van den Boom, P. 1999. New or interesting lichens and lichenicolous fungi from Belgium and Luxembourg. VIII. Lejeunia 162: 1-95.

Skirina, I. F. 2010. Addition to lichen flora of islands and coast of Peter the Great Bay (the Sea of Japan, Primorie Territory). Novosti sistematiki nizshikh rastenii 44: 221-236. (In Russia with English abstract). https://doi.org/10.31111/ nsnr/2010.44.221

Spribille, T., Pérez-Ortega, S., Tønsberg, T. \& Schirokauer, D. 2010. Lichens and lichenicolous fungi of the Klondike Gold Rush National Historic Park, Alaska, in a global biodiversity context. The Bryologist 113: 439-515. https://doi. org/10.1639/0007-2745-113.3.439

Spribille, T., Fryday, A. M., Pérez-Ortega, S., Svensson, M., Tønsberg, T., Ekman, S., Holien, H., Resl, P., Schneider, K., Stabentheiner, E., Thüs, H., Vondrák, J. \& Sharman, L. 2020. Lichens and associated fungi from Glacier Bay National Park, Alaska. The Lichenologist 52: 61-181. https:// doi.org/10.1017/S0024282920000079

Urbanavichene, I. N. \& Urbanavichus, G. P. 2018. Contributions to the lichen flora of the Stavropol Territory (Central Caucasus, Russia). Novosti sistematiki nizshikh rastenii 52(2): 417-434. (In Russian with English abstract). https://doi. org/10.31111/2018.52.2.417

Urbanavichus, G. P. 2010. A checklist of the lichen flora of Russia. Nauka, St. Petersburg. 194 pp. 
Urbanavichus, G. 2016. Additions to the lichens and lichenicolous fungi of Pasvik Reserve, Murmansk region, Russia. Graphis Scripta 28(1-2): 8-10. https://doi.org/10.13158/heia.28.1.2015.185

Urbanavichus, G. P. \& Urbanavichene, I. N. 2009. New and rare lichens and lichenicolous fungi species for Murmansk Region from the Lapland Reserve. Novosti sistematiki nizshikh rastenii 42: 189-197. (In Russian with English abstract). https://doi. org/10.31111/nsnr/2008.42.189

Urbanavichus, G. \& Urbanavichene, I. 2014. An inventory of the lichen flora of Lagonaki Highland (NW Caucasus, Russia). Herzogia 27: 285-319. https://doi.org/10.13158/heia.27.2.2014.285

Urbanavichus, G., Motiejūnaitè, J., Kukwa, M. \& Urbanavichene, I. 2007. Contribution to the biota of lichens and lichenicolous fungi of Murmansk region (NW Russia). Botanica Lithuanica 13(3): 197-202.

van den Boom, P. P. G. 2013. Further new or interesting lichens and lichenicolous fungi of Tenerife (Canary Islands, Spain). Stapfia 99: 52-60.

Zhurbenko, M. P. 2009a. Lichenicolous fungi and some lichens from the Holarctic. Opuscula Philolichenum 6: 87-120.

Zhurbenko, M. P. 2009b. Lichenicolous fungi and lichens from the Holarctic. Part II. Opuscula Philolichenum 7: 121-186.

Zhurbenko, M. P. 2010. New and interesting lichenicolous fungi from Eurasia. II. Mycosphere 1(3): 213-222.

Zhurbenko, M. P. 2013. Hainesia peltigerae sp. nov. and some other interesting lichenicolous fungi from Eurasia. Graphis Scripta 25: 39-43.

Zhurbenko, M. P. 2020. Lichenicolous fungi from the Holarctic. Part III: New reports and a key to species on Hypogymnia. Opuscula Philolichenum 19: $180-189$.

Zhurbenko, M. P. 2021. Lichenicolous fungi from the Holarctic. Part IV: New reports and a key to species on Dermatocarpon. Opuscula Philolichenum 20: 44-53.
Zhurbenko, M. P. \& Ohmura, Y. 2019. New and interesting records of lichenicolous fungi from the TNS herbarium: Part I. Opuscula Philolichenum 18: 74-89.

Zhurbenko, M. P. \& Pino-Bodas, R. 2017. A revision of lichenicolous fungi growing on Cladonia, mainly from the Northern Hemisphere, with a worldwide key to the known species. Opuscula Philolichenum 16: 188-266.

Zhurbenko, M. P. \& Vershinina, S. E. 2014. Opegrapha bryoriae sp. nov. and other lichenicolous fungi from Asian Russia. Herzogia 27: 93-109. https:/ / doi.org/10.13158/heia.27.1.2014.93

Zhurbenko, M. P. \& Yakovchenko, L. S. 2014. A new species, Sagediopsis vasilyevae, and other lichenicolous fungi from Zabaikal'skii Territory of Russia, southern Siberia. Folia Cryptogamica Estonica 51: 121-130. https://doi.org/10.12697/ fce. 2014.51 .14

Zhurbenko, M., Diederich, P. \& Otnyukova T. 2008. Plectocarpon hypogymniae (Roccellaceae), a new lichenicolous species from Siberia. The Bryologist 111: 328-330. https://doi.org/10.1639/0007-2 745(2008) 111[328:PHRANL]2.0.CO;2

Zhurbenko, M. P., Himelbrant, D. E., Kuznetsova, E. S. \& Stepanchikova, I. S. 2012. Lichenicolous fungi from the Kamchatka Peninsula, Russia. The Bryologist 115: 295-312. https://doi. org/10.1639/0007-2745-115.2.295

Zhurbenko, M. P., Chesnokov, S. V. \& Konoreva, L. A. 2016. Lichenicolous fungi from Kodar Range, Trans-Baikal Territory of Russia. Folia Cryptogamica Estonica 53: 9-22. https:/ /doi.org/10.12697/ fce.2016.53.02

Zhurbenko, M. P., Enkhtuya, O. \& Javkhlan, S. 2019. A first synopsis of lichenicolous fungi of Mongolia, with the description of five new species. Plant and Fungal Systematics 64(2): 345-366. https://doi. org/10.2478/pfs-2019-0023 